\section{TECHNICAL EDUCATION.}

BY ALEXANDER MEEK, MUSEUM, PETERHEAD, SCOTLAND.

Mr. Morse has recently, in the Atlantic Monthly, advocated, and very ably, the extension of museums into the smaller towns. The success of the public libraries is as well known on this side as in America, and where museums have been established they have also been largely taken advantage of. And thus it is only fair that some definite purposes should be kept in view in their formation and in their arrangement. Such purposes the writer has set down elsewhere*, and there is little indeed to add or object to in the article above mentioned.

I hope soon to publish a description of a local museum, which has long had a quiet and dark existence in Peterhead, but which, with the institution of a reading room and free library, is now properly housed. The removal has been made the occasion of a complete revival and rearrangement in new cases. We hope to have it opened in a week or two.

There is no doubt at all of the educational value of such institutions. The pity is that so many are hampered by want of funds to carry on the work and to provide a neat-handed, educated person to look after the collection. Were it possible to build such museums and libraries with other educational activities, I fancy the solution of the problem of providing for education, even in remote districts, would be brought to practicable ground and might be gone on with at once.

Let me tell those who read Science one direction which education has recently taken in this country, and some thoughts that are suggested for its continuance and furtherance.

In towns, the youth who takes up a work or profession, is led at once, by contact with his fellows, to attend University or Evening Technical classes, where he learns principles underlying his daily work. But in the country districts, until lately, little attempt has been made to instruct farmers and fishermen.

And like all similar attempts, even when made in towns, the failure of the work was by many guaranteed. Those who have passed from school to university, who have devoted themselves to some special department of learning; furnish often the worst enemies to the scheme. But the funds came suddenly, and the trial was made. Well, it may be granted at once that an itinerant instructor can do very little real teaching, but if he can successfully, every night of his course, hold up an attractive picture of scientific work and its results to those in front of him, he should, if well trained, find that his work is not unavailing, that it is possible to thus stimulate an interest in the questions he handles, and then the free libraries are called upon that the pupil may follow it up. I can vouch, from my own experience in this field, for the interest taken in the lectures and for the encouraging enthusiasm evinced by those who attend-many travelling six miles for the purpose. The interest shown, of course, is due, in my case, to the country audience being so directly interested in my subject-the Farm Animals.

But still there is here, as with the museums, the want of co-ordination. Not only is such instruction very much needed in the country, and the desirability of the schoolmasters taking the great share of it, but a number of good central institutions in the larger towns where such a complex subject as agriculture could be taught by competent teachers in all the departments and with which the schoolmasters and itinerant instructors would have direct connection.

Should such an extension be adopted in America, I

*Transactions of Buchan Field Club for 1893 , etc. think you will see the desirability of having it emanate from such institutions of agriculture as are to be found in Germany, and as in Guelph, Canada, on your side.

With the schoolboards, the Science and Art Department and the Technological Institution in London, and the County Councils, not to add universities, free libraries and museums, we have institutions enough in Britain, but their want of connection and independence of effort are much to be deplored.

It would be invidious in a journal like Science to discuss how that may be done. But for the purpose alike advocated by the writer in the Atlantic Monthly and of extending education into the country, such co-ordination is to be recommended.

\section{PALENQUE HIEROGLYPHICS.}

BY PH. J. J. VALENTINI, 35 I LENOX AVE., NEW YORK CITY.

I HAVE prepared a memoir, in which an accurate account is given, both of the sculptured centre-picture set into the rear wall of the so-called Temple of the Cross, Palenque, and of the text contained in the 201 squares of hieroglyphics on the two lateral tablets.

Since the discovery of this temple by J. Tloyd Stephens, in 1849 , this text has been the subject of much speculation. It was thought to tell the migratory and colonial history of the fabled Toltec nation. It was imagined to be written in hieroglyphics capable of being deciphered by the aid of a proferred alphabet. Neither of these speculations will stand the test.

As to the structure itself, it stands on a small tumulus, and was devoted to the memory of a defunct priest, whose name does not appear. But his portrait seems to be represented in the large sacrificial scene. He is offering the idol of Chac to the sacred Quetzal, this bird being perched on the top of the Tree of Life (yak-die), the latter standing. on a pedestal in the shape of a grotesque human skull.

The purport of the left-hand tablet, as may be inferred from certain peculiar features and their arrangement, is that of a brief abstract of the records of the Palenque Temple. The other lateral tablet appears to contain a sort of biography of the dead priest.

With the exception of only two symbols of the twenty Maya days, the remaining exhibit the same features as are known from Landa's work and the extant codices, only that they show themselves in most elaborate form.

No symbol for the month makes its appearance on these tablets. Mr. Foerstemann's theory of reading doublecolumns is untenable; consequently, also, that of his daysymbols allied to month-symbols. The one is contradicted by the conspicuous separation of the columns themselves and by many other reasons. The other is refuted by literary statements. Landa's pictures of month-symbols are not the traditional ones, but fanciful suggestions.

There is no trace on the tablets of the Mexican Tonalamatl reckoning, but, rather, of that of the ancient Tulan (Palenque) vigesimal system.

A phonetic base underlies the text neither as a whole nor in part. The hieroglyphics are of pure ideogrammatic nature. Moreover, the eye will not meet any object profane. The squares show only objects sacred, belonging to the cult, the temple, or such as were brought to it with the purpose of sacrificial offering's. Their identification offers no difficulties. Almost all of them were described and discussed by Landa.

At the suggestion of the lamented Professor Baird, Smithsonian Institution, this memoir was begun in 1873 . Its substance was ready for print in 1877, when I made an agreement with Dr. Rau, that he should first publish the description of the Palenque tablet, No. II., which stands preserved in the National Museum, and I then fol- 